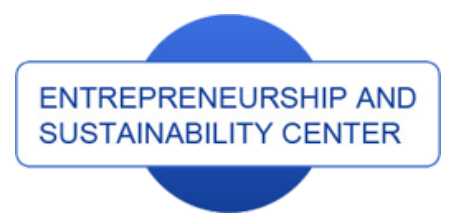

Publisher

http://jssidoi.org/esc/home

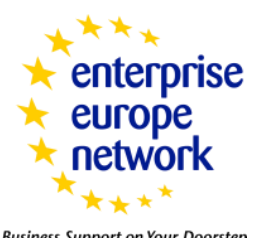

Business Support on Your Doorstep

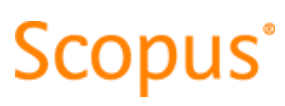

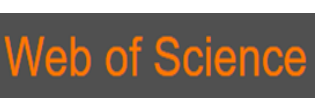

1 Clarivate

\title{
INTERNAL FACTORS INFLUENCING THE COST OF EQUITY CAPITAL *
}

\author{
Natalia Mokhova ${ }^{1}$, Marek Zinecker ${ }^{2}$, Tomáš Meluzín ${ }^{3}$ \\ ${ }^{1,2,3}$ Brno University of Technology, Faculty of Business and Management, Kolejni 2906/4, CZ-612 00 Brno, Czech Republic \\ E-mails: ${ }^{1}$ mokhova.natalia@gmail.com; ${ }^{2}$ zinecker@fbm.vutbr.cz (corresponding author); ${ }^{3}$ meluzint@fbm.vutbr.cz
}

Received 25 January 2018; accepted 10 May 2018; published 30 June 2018

\begin{abstract}
In this paper we compile and evaluate the research available on internal factors influencing the cost of equity capital. The topic has been extensively studied for the past few decades; however, the information is spread and is not accumulated. We begin by reiterating the reasons why information asymmetry drives financial decisions. Next, we review recent literature that focuses on financial disclosure and accounting information, i.e. internal factors that are directly connected with information asymmetry. In the remainder of our review we discuss a recent debate on the impact of corporate governance and social factors. Aside from theoretical contribution, the comprehensive literature review of existing studies results in formulation of a strategy how to decrease to cost of equity capital by means of internal factors adjustments. We believe that highlighting the key points in the debate will be beneficial for both academicians and practitioners who will be able to form an independent view of the approaches how to take influence on the cost of equity capital.
\end{abstract}

Keywords: cost of equity; costs reduction; corporate governance; information asymmetry; disclosure policy; social responsibility

Reference to this paper should be made as follows: Mokhova, N.; Zinecker, M.; Meluzín, T. 2018. Internal factors influencing the cost of equity capital, Entrepreneurship and Sustainability Issues 5(4): 827-845. http://doi.org/10.9770/jesi.2018.5.4(9)

JEL Classifications: G3, M4, D8

\footnotetext{
* This research was supported by the Institute of Economic Research Toruń, Poland. Project Title: Analysis of Relations among Capital Markets of European Union Countries. Project Registration No.: 2016/1.
} 


\section{Introduction}

The factors of internal environment facilitate the strengths and weakness of a company that in turn affect its development and all company's activities. Compared to the external environment represented by macroeconomic and capital market environment (for more details see e.g. Faldzinski et al., 2016; Zinecker et al., 2016; Lenart et al., 2016; Vukovic et al, 2017; Mazur, 2017; Kovacic \& Vilotic, 2017; Pietrzak et al, 2017; Meluzin et al., 2017) a company is able to manage the internal factors while influencing the business processes in order to achieve its targets. The capital management is one of the most significant elements of decision-making process. Moreover, effective financial decisions supported by the information regarding the relation between internal factors, the capital and its cost result as a clue to the stable successful development of a company.

There are many research papers dedicated to different aspects of the cost of equity capital (hereinafter referred to as CEC) management (see e.g., Michalak, 2016; Pieloch-Babiarz, 2017; Tomczak, 2017; Pustylnick, 2017; Dokulil et al., 2017). As a rule the internal factors and their impacts that are analysed by international scientists can be divided into several groups as corporate disclosure, corporate governance, social performance and other financial related performance. The information and its asymmetry are an important link between the CEC and other factors. The influence of variety of internal factors on the costs of equity capital has been extensively studied for the past few decades; however, the information is spread and is not accumulated. As a rule the studies is focused on one factor or a group of related factors.

In this paper we accumulate and evaluate the knowledge on the internal factors influencing the CEC. Because this literature review can represent only a small part of the academic resources, with a focus on very recent articles, we refer the reader to recent surveys by authors listed in references for additional reading.

The rest of this paper proceeds as follows. First, we provide an overview of the methodological approach. Next, we review and discuss the literature on information asymmetry, financial disclosure, accounting information, corporate governance and social factors. Aside from theoretical contribution, the paper provides a practical input in terms of proposals how to reduce the cost of equity in the last section.

We believe that highlighting the key points in the debate will be beneficial for both academicians and practitioners who will be able to form an independent view of the approaches how to take influence on the cost of equity.

\section{Methodology}

The article is of theoretical-cognitive and methodological character. The research is based on a systematic review of recent academic literature. Kitchenham (2004) reports that a systematic review "is a means of identifying, evaluating and interpreting all available research relevant to a particular research question, or topic area, or phenomenon of interest". A systematic literature review is a form a secondary study that uses other studies as its data. In this systematic literature review we aim to understand an established but very fragmented topic; this fact justifies relevance of our research (for details see Webster, Watson, 2002; Kitchenham, 2004).

This study has been processed in several discrete activities including planning, defining a search strategy, database searching, selecting studies, synthetizing and expert interpretations - reporting the review (Kitchenham, 2004).

We applied a general approach to the search strategy that includes identifying existing systematic reviews and assessing the volume of potentially relevant studies, trial searchers using various combinations of search terms 
derived from the research topic, reviews of research results and consultations with experts in the field as recommended by Kitchenham (2004).

The main searches for primary studies were undertaken while using international databases as Scopus, ScienceDirect, EBSCO, Emerald and ProQuest Central. In addition other sources of evidence were collected manually in state libraries as Moravian Library (Brno), Library of the Brno University of Technology, Bibliothèque nationale de France (Paris), Dauphine University Library (Paris), Library of the Vienna University of Economics and Business and Russian State Library (Moscow). As the sources and availability of data is crucial for quantitative research then multifold resources are used to collect data.

Once the list of potentially relevant primary studies has been completed, an assessment for their actual relevance was conducted. Inclusion and exclusion criteria were defined to reduce a huge number of potentially relevant studies. Only those primary studies were considered if key words related to the topic were included in 1) titles, 2) abstracts and 3) full paper contents. All passages of the particular text related to the topic were marked and a conceptual model in the form of a concep-tual matrix was created. A list of included and excluded studies was established where the reasons for exclusion are listed. In accordance with Kitchenham (2004) and Tranfield et al. (2003) the data collection matrix provides standard information including date of data extraction, title, authors, journal, publication details and a space for additional notes.

The next step was devoted to a deep literature analysis, where the previous studies are analysed more precisely, in order to identify the existing relations, causes and consequences of the analysed phenomena. Based on the literature research eighteen internal factors were identified that that are reported to have influence on the CEC. Moreover, the findings assist to indicate the significance and direction of this influence.

Hereafter, the analysis and synthesis results are reported. The internal factors are defined as factors associated with corporate activities that can be influenced by corporate managers. The internal factors can be classified in several categories: corporate disclosure, corporate governance and social factors. However, there is one singular factor that can be represented as a linkage between many factors and the CEC: the information asymmetry. E. g., higher corporate disclosure leads to lower information asymmetry that in turn decreases the CEC. The corporate disclosure policy is designed to increase transparency and decrease information asymmetry that in turn is reflected in company's performance. The discloser can be presented as a set of individual factors, but it can include several separate internal factors that have their own degree of influence on the CEC and that were analysed separately in this study.

We believe that our systematic review extends the theoretical knowledge of the investigated subject significantly while accumulating very spread information on factors influencing internal CEC. We first present a review of theories and research approaches for studying internal factors while simultaneously looking for links among them. Until recently, researchers have been only focused on the role of one single factor.

\section{Results and discussion}

\section{The essence of information asymmetry}

The availability of information is an essential factor in the decision-making process regarding the efficiency of resource allocation on micro and macro levels. The inequality of available information between corporate insiders and stakeholders as investors is thought of as information asymmetry. 
The International Journal

ENTREPRENEURSHIP AND SUSTAINABILITY ISSUES

ISSN 2345-0282 (online) http://jssidoi.org/jesi/

2018 Volume 5 Number 4 (June)

http://doi.org/10.9770/jesi.2018.5.4(9)

Back to Myers (1984) and Myers, Majluf (1984) who argue that information asymmetry drives financial decisions, the situation, when the private information exceed the publicly available information about future corporate performance, leads to higher CEC required by less informed inves-tors. Barron et al. (2012) show that information leads to higher CEC (CEC). In addition, they find that average precision and precision of public information are negatively associated with CEC. At the same time the precision of private information positively influences the CEC, however the coefficient is relatively small. Besides, with lower public information the precision of private information reduces the cost of capital.

Authors also try to analyse information asymmetry and its impact on CEC through different angles. For example, Armstrong et al. (2010) examine the influence of information asymmetry on the cost of capital according the market competition. If market is imperfect, the information asymmetry has a significant effect on the cost of capital; and there is no impact, if there is a perfect market competition. Thus, the studies investigating relation between information asymmetry and the cost of capi-tal, should take into account the level of market competition.

As the information asymmetry is very wide term, the researchers apply different types of proxies to estimate the information asymmetry component in the CEC. The most popular measure among researchers is bid-ask spread (Leuz, Verrecchia, 2000; Armstrong et al., 2010), which represents the difference between the ask price and the bid price of a share. The bid-ask spread refers to the adverse selection problem that emerges in shares transactions with asymmetrically informed investors. Thus less information asymmetry is associated with less adverse selection that in turn leads to a smaller bid-ask spread. The alternative measure of asymmetric information is trading volume, which refers to the liquidity. It represents the willingness of investors to sell the shares or to buy them that in turn is related to the existence of information asymmetry. Another measure as share price volatility also is used as a proxy of information asymmetry (Lang, Lundholm, 1993; Leuz, Verrecchia, 2000; Masood et al., 2017). The smooth transitions in share prices stand for the absence of information asymmetry; the higher level of volatility indicates the increasing information asymmetry between a company and shareholders or even between investors. However, the alternative proxies as trading volume or price volatility might be affected also by other factors than information asymmetry (Leuz, Verrecchia, 2000). Consequently, there can be the combination of several proxies to measure information asymmetry. For example, Armstrong et al. (2010) use five measures to estimate infor-mation asymmetry: two market-based measures as (1) the adverse selection component of the bidask spread (ASC spread) and (2) the bid-ask spread; two accounting-based measures as (3) the ratio of annual research and development expense to sales and (4) scaled accruals quality; (5) analyst coverage. The last one represents "the number of sell-side analysts issuing one-year-ahead earnings-per-share forecasts for the firm during the year". The greater analyst coverage might improve the information environment that in turn leads to a lower information asymmetry. As was mentioned before the market-based proxies are widely used among researchers. According to authors the advantage of ASC spread and spread itself is the precisely measurement of the information asymmetry outcome. The existence of information asymmetry results in ASC spread increase. In terms of accounting-based measures the R\&D expense represents the intangible assets, which in turn might be associated with information asymmetry. At the same time the higher variance of scaled is associated with lower earnings quality that in turn leads to higher information asymmetry. Barron et al. (2012) also use analyst coverage to measure information environment characteristics, including the infor-mation asymmetry. Their approach takes into consideration the expected dispersion of analyst fore-cast, as well as squared errors in the mean forecasts based on historical data and the number of analyst following.

The information asymmetry can be treated as idiosyncratic volatility. Therefore, in order to reduce idiosyncratic component of CEC, the level of disclosure can used as influential tool to decrease information asymmetry between managers and investors (Lopes, de Alencar, 2010). 


\section{Accounting information and corporate disclosure policy}

The internal factor which is directly connected with information asymmetry represents financial disclosure. Financial disclosure is considered as an important part of corporate governance (Ashbaugh et al., 2004; Byun et al., 2008; Pae, Choi, 2011, Paseková et al., 2018).

The quality of accounting information and its transparency decrease the information and agency risks. There is no doubt to say that disclosure reduce information asymmetry and as a result decrease the cost of capital. The information asymmetry represents the adverse selection into transactions between buyers and sellers, and therefore reduces liquidity in company's shares (Copeland, Galai, 1983; Kyle, 1985). This effect occurs in three ways. Firstly, investors demand a risk premium for bearing information risk. In turn, disclosure reduces it, consequently risk premium decreases and as a result CEC. Secondly, higher disclosure decreases estimation risk and thirdly it enhances stock market liquidity and as a result reduce transaction cost that leads to lower CEC.

\section{Accounting information}

Accounting information plays a great role in the decision making process and other firm's activities. Moreover, its quality and quantity might decrease or increase the information asymmetry and as a result have an impact on the cost of capital. Many researches examine the different aspects of accounting information and their influence on the capital costs.

Firstly, Easley and O'Hara (2004) investigate the influence of private and public information on the cost of capital with further development of asset-pricing model, where both types of information affect asset returns. Investors demand higher return to the companies with greater private information and correspondingly less public. Private information causes additional systematic risk and thus an investor requires compensation for that kind of risk. According to their equilibrium a com-pany with information that is more private and less public faces a higher CEC.

Lately Li (2005) finds that low precision of noisy information about the expected aggregate dividend growth rate increases the risk premium and stock return volatility and in turn the precise information decreases the risk premium and as a result the cost of capital.

Apergis et al. (2011) provide theoretical model, which shows that "an increase in expected cash flows, coming from improvements in the quality of accounting information, leads to a reduction in the firm's cost of capital". From the model the authors point out several factors leading to the cost of capital reduction: (1) "the decline of the variance in the idiosyncratic variation in firm's cash flows"; (2) "the decline of the variance in the common variation in firm's cash flows with the mar-ket"; (3) "the increase in the shareholder's base of the economy or alternatively the increase in the number of investors who participate in the market"; (4) "the increase in the risk tolerance of the market"; and (5) the increase in the firm's expected cash flows".

The corporate earnings as a significant element of accounting information are a widespread subject of research. The earnings are the significant part of accounting information, which can be disclosed, in order to reduce the risk of information asymmetry. Consequently, the earnings characteristics are examined as factors influencing the CEC. One of the most indicative attributes of earnings is earnings smoothness. It is generally thought among executives that earning smoothness might lead to lower cost of capital. However, McInnis (2010) finds that there is no relation between earnings smoothness and average stock returns over 30 years period. At the same time there is evidence that inverse association between cost of capital and earnings smoothness is driven by optimism in ana- 
lysts' long-term earnings forecasts. Consequently, companies with volatile earnings do not experience high returns.

Another significant earnings characteristic is their quality level. The researchers determine that low quality of earnings increase information asymmetry, which lead to higher CEC (Aboody et al., 2005; García Lara et al., 2011). For instance, Apergis et al. (2012) empirically investigate the influence of accounting information and the earnings quality on the cost of capital. According to authors higher quality represents higher precession of public disclosure; when lower level of private information minimizes gains obtained by privately informed investors. The quality of earnings is defined by the absolute value of the abnormal component of accruals: the higher absolute value is associated with lower quality. The authors conclude that discretionary accruals as a measure of earnings quality are important proxy for corporate information environment. The abnormal component of accruals reduces the effectiveness of public earnings announcements that in turn increases the risk of information asymmetry.

Further, conservatism represents another attribute of earnings quality from the view were earnings are determined to evaluate economic income. In terms of transparency and information asymmetry the concept of accounting conservatism has been occurred. In 1980 the Financial Accounting Statements Board developed the Statement of Financial accounting Concepts, where conservatism was defined as "a prudent reaction to uncertainty to try to ensure that uncertainties and risks inherent in business situations are adequately considered". Givoly and Hayn (2000) define conservatism as "a selection criterion between accounting principles that leads to the minimization of cumulative reported earnings by slower revenue recognition, faster expense recognition, lower asset valuation, and higher liability valuation". They also determine two measures of conservatism: (1) the sign and magnitude of accumulated accruals over period of time; and (2) the excess of the relation between stock price movements and earnings signals in "bad news" periods of time over such relation in "good news" periods. Watts (2003) points out the alternative explanations of conservatism as contracting, shareholder litigation, taxation and accounting regulation. In general terms, the accounting conservatism can be classified as ex post (also named as conditional or news-dependent) and ex ante (also named as unconditional, news independent). Ex ante conservatism represents "aspect of the accounting process determined at the inception of assets and liabilities yield expected unrecorded goodwill". Ex-post conservatism refers to situation when "book values are written down under sufficiently adverse circumstances but not written up under favourable circumstances, with the latter being the conservative behaviour" (Beaver, Ryan, 2005).

As accounting conservatism incorporate transparency and timeliness of financial reporting, many researchers investigate its influence on the CEC as one of the information characteristics. Chan et al. (2009) find that ex ante conservatism leads to lower CEC. Ex ante and ex post conservatism provide different information about the quality of a firm's current and future earnings to equity investors. Ex ante conservatism leads to lower CEC because it provides more persistent and predictable current and future earnings streams and therefore ensures good quality earnings and accounting information to the market. In addition, companies, with higher level of ex ante accounting conservatism have lower CEC despite the level of leverage, the firm's size, earnings variability. Later Artiach and Clarkson (2010) also find negative relation between ex ante firm-level conservatism and CEC; however, the association becomes weaker with low information asymmetry.

Besides the conditional conservatisms is also significantly negatively related to CEC. Basu (1997) determines conditional conservatism as "more timely recognition in earnings of bad news regarding future cash flows than good news" that can be explained by hire sensitivity of earnings to negative unexpected returns rather that to positive. Later based on the empirical evidence García Lara et al. (2011) argue that conditional conservatism leads to higher information precision, increased company value and lower CEC by the means of decreasing the uncertainty in amount and distribution of the future cash flows and volatility of future stock prices. In another 
The International Journal

ENTREPRENEURSHIP AND SUSTAINABILITY ISSUES

ISSN 2345-0282 (online) http://jssidoi.org/jesi/

2018 Volume 5 Number 4 (June)

http://doi.org/10.9770/jesi.2018.5.4(9)

words additional conservatism decreases information asymmetry problems, improves investment efficiency and results in stronger corporate governance. The research conducted by Mikhail et al. (2004) shows that companies with repeated surprising quarterly earnings announcement experience higher cost of capital. Moreover, the sign of earning surprise does not influence the outcome. In another words, the market take into consideration the smoothness of earnings to a greater extent rather than the pattern of news (i.e. bad or good news).

Summing up, there is no doubt that high quality accounting information reduces the information asymmetry that in turn alleviates the conflicts between managers and investors and as result lead to lower CEC.

\section{Corporate disclosure policy}

As was mentioned before the disclosure level is associated with information asymmetry; in another words higher disclosure represents more transparent and available information. The corporate dis-closure or transparency can be defined as ,the widespread availability of firm-specific information concerning publicly listed firms in the economy to those outside the firm" (Bushman et al., 2004).

First of all, disclosure can be divided into two ways: institutional (or mandatory) and voluntary. The first one is required by laws and regulations and widely is used among companies. The voluntary disclosure depends on the company's incentives to inform investors better. The institutional and voluntary disclosure can be complements or substitutes. The country's accounting laws provide a minimum standard for its listed companies, indicated what kind of information has to be disclosed. However the managers have discretion to voluntary provide additional information above requirements.

Bushman et al. (2004) divide corporate transparency into two dimensions: (1) financial transparency and (2) governance transparency. They argue that the financial transparency is related to political regime and governance transparency is associated with legal regime. Under their framework the corporate information mechanism can be classified into three categories: corporate reporting, private information acquisition, and information dissemination. Following Bushman et al. (2004) DeBoskey and Gilett (2013) conduct factor analysis of ten corporate transparency variables used by other researchers and identify four independent dimensions of corporate disclosure: public disclosure information, intermediary information, earnings quality information and insider information. They also investigate the influence of these variables on the CEC and other corporate performance. Their findings show that intermediary information transparency and insider information transparency are significantly associated with CEC. Myskova and Hajek (2016) assess the impact of the information published in annual reports of companies on the market value of shares. They show that net optimism in annual reports is perceived positively by stakeholders.

One of the most difficult challenges in corporate disclosure research is the choice of appropriate proxy for disclosure. The key problems of disclosure measurement are difficulty in the identification of the full population of disclosures and difficulty to consistently classify the form and type of disclosure. As a rule researchers might use two alternative approaches to measure disclosure: own created disclosure indices or ratings produced by external parties. The advantage of the researchers constructed disclosure indices is ability to be applied a widely range of companies, compare to external agency' indices which are limited to companies covered by these external parties. On the other hand, researcher constructed index contains subjective opinion and explanation. The external indices have also several disadvantages. Firstly, they might be a time limitation. Secondly, the external scores represent analysts' understanding of disclosure quality rather than disclosure quality of a company. On the contrary the advantage of this approach is the fact that it is constructed by pri-mary users of the disclosure information, moreover, they are experts in the investigated industry and familiar with a company. In another words there is higher adequacy of external indices in terms of specific companies or industries (Artiach, Clarkson, 
The International Journal

ENTREPRENEURSHIP AND SUSTAINABILITY ISSUES

ISSN 2345-0282 (online) http://jssidoi.org/jesi/

2018 Volume 5 Number 4 (June)

http://doi.org/10.9770/jesi.2018.5.4(9)

2011). For example, Lopes and de Alencar (2010) develop Brazilian Corporate Disclosure Index, which measure disclosure across several di-mensions: “... (1) general information about the firm; its market, and major events over the last year; (2) relations to employees and managers regarding compensation and policies; (3) non-financial information about markets, sales, and products; (4) information about forecasts of sales, cash flows, and earnings; (5) discussion and analysis of financial data, including tie series information about performance and explanations of past behaviour; and (6) other information". In total there are 47 attributes, which were collected from annual reports, websites and other public sources. Earlier Richardson and Welker (2001) also use disclosure rating as proxy for disclosure, which includes 20 categories from corporate annual reports. Baginski and Rakow (2012) use three dimensions to determine the quality of voluntary disclosure represented by management earnings forecast: (1) whether a company is "a supplier of at least one quarterly management earnings forecast over 16 quarters"; (2) forecast frequency of private information revelation; and (3) the precision of forecast. Table I summarizes implied measures of corporate disclosure in the selected studies on the relation between corporate disclosure and CEC.

In the same way many studies have shown that both mandatory and voluntary disclosure decrease the CEC by the means of information asymmetry reduction. Chen et al. (2010) investigate the influence of mandatory disclosure on the cost of capital at the US market. In 2000 the Securities and Exchange Commission's Regulation Fair Disclosure (RFD) has become effective, which "prohibits selective disclose of material information to a subset of market participants, such as analysts and institutional investors, without simultaneously disclosing the same information to the investing public". The purpose of such mandatory disclosure is to increase investors' confidence and provide equal access to information. The findings show that there is a significant decline in the cost of capital for medium and large companies in the post-RFD period; i.e. mandatory disclosure leads to lower CEC. The latest research also indicates the negative relation between mandatory disclosure and CEC. Based on the international evidence for the period between 1990 and 2004, Core et al. (2015) find that mandatory disclosure quality significantly decreases the CEC. In addition they incorporate into model the inside ownership, which strengthens the direct influence of disclosure.

Table 1. The corporate disclosure measurement

\begin{tabular}{|l|l|c|}
\hline Study & Measure of disclosure & Region \\
\hline Richardson and Welker, 2001 & $\begin{array}{l}\text { Financial disclosure rating based on annual } \\
\text { reports }\end{array}$ & Canada \\
\hline Lopes and de Alencar, 2010 & $\begin{array}{l}\text { BCDI (Brazilian Corporate Disclosure } \\
\text { Index) }\end{array}$ & Brazil \\
\hline Kim and Shi, 2011 & $\begin{array}{l}\text { Managements earnings forecasts } \\
\text { (bad/*good news) }\end{array}$ & USA \\
\hline Baginski and Rakow, 2012 & $\begin{array}{l}\text { Management earnings forecast disclosure } \\
\text { policy (three dimension measure) }\end{array}$ & USA \\
\hline Barth et al. 2013 & Transparent earnings & USA \\
\hline DeBoskey and Gillett, 2013 & $\begin{array}{l}\text { Multi-dimensional corporate transparency: } \\
\text { public disclosure information, intermediary } \\
\text { information, earnings quality information, } \\
\text { insider information }\end{array}$ & USA \\
\hline
\end{tabular}

Source: Authors' composition

Besides, some researches investigate disclosure more specifically. For instance, Barth et al. (2013) analyse the relation between transparent earnings and lower cost of capital; they find that more transparent earnings lead to lower cost of capital. The low transparency might push some investors to private information acquisition. As a rule, such information about company's economic value is costly and investors would cover expenses by the means of higher required premium. 
Summing up, the higher disclosure leads to more liquid markets that in turn reduces risks and decreases the CEC.

\section{Corporate governance and its elements}

Corporate governance and its elements is an essential factor influencing the CEC. There is no unique precise definition of corporate governance. According to Claessens and Yortoglu (2013) the conception of corporate governance can be divided into two types. The first type of definition un-covers the behavioural patterns of this term: behaviour of a company in terms of efficiency, perfor-mance, financial structure, growth, treatment of shareholders and stakeholders. From this perspec-tive corporate governance can be define as "the complex set of constrains that determine the quasi-rents (profits) generated by the firm in the course of relationship with stakeholders and shape the ex post bargaining over them". The second type unfolds the normative framework of the term: legal and judicial system, financial and labor markets regulations. On this view the corporate governance can be defined based on the functional approach. The corporate governance can be characterized as the selection of institutions and policies that are involved in the following functions related to com-panies: (1) pooling resources and subdividing sharers; (2) transferring resources across time and space; (3) risk management; (4) generating and providing information; (5) dealing with stimulating problems; and (6) resolving competing claims on the funds generated by the companies. As Ash-baugh et al. (2004) notice "...corporate governance encompasses a broad spectrum of mechanism intended to mitigate agency risk by increasing the monitoring of management's actions, limiting managers' opportunistic behaviour, and improving the quality of firm's information flows".

Many researchers create their own indexes of corporate governance measurement. As a rule, they divided it into several categories (Table II). The most used attributes of the corporate governance are as follows: board structure, ownership structure, shareholder rights, information quality and disclosure, and audit committee independence.

Ashbaugh et al. (2004) find that corporate governance has a significant influence on the CEC. In particular, the companies reporting larger abnormal accruals have a higher cost of equity; at the same time the companies with more transparent earnings and more independent audit committees face lower CEC. The concentrated ownership represented by the number of blockholders also has a positive relation, i.e. blockholders increase the agency problems, thereby rise CEC. Likewise Byun et al. (2008) find that corporate governance reduces the CEC as the result of agency problems and information asymmetry reduction. They argue that shareholder rights protection has the most signif-icant influence on the CEC. At the same time the board of directors and disclosure also reduce CEC.

The quality of corporate governance plays significant role in degree of the effect on the CEC. Ali Shah and Butt (2009) investigate the influence of the quality of corporate governance on the expected CEC. They use the Corporate Governance Score as a measure for the corporate governance quality. The research based on the Pakistan listed non-financial companies shows that board size is nega-tively related to the CEC, i.e. the larger board lead to lower cost of equity. In addition, managerial ownership has negative influence on the cost of equity, i.e. a higher number of shares held by board members leads to the higher CEC. Moreover, the board independence and audit committee inde-pendence have a positive and insignificant influence on the CEC. Thus, the companies with stronger corporate governance face lower CEC. Similarly Zulkufly (2012) indicates the quality of corporate governance based on the six categories as board structure and procedures, board compensation prac-tices, shareholder rights and relations, accountability and audit, transparency and social and envi-ronment (139 items in total). A higher quality of corporate governance leads to lower CEC for Ma-laysian listed companies. However, the significance of separate categories impact varies. The board structure and procedure, shareholder rights and relations, and accountability and audit characteris-tics are significant in explaining the level of CEC. At the same time, the influence of board compensation practices, transparency and ethic and social activities is not significant. 
Later Mazzotta and Veltri (2014) apply more specific corporate governance index to indicate the influence of corporate governance on the CEC for companies listed on the Italian stock exchange. This index includes four dimensions of board characteristics: board independence, board size, exist-ence of internal board committees and independence of board committees. Pae and Choi (2011) investigate the influence of comprehensive corporate governance on a value premium. They find that stronger corporate governance leads to the lower CEC. Moreover, the beneficial effect of corporate governance on the CEC is stronger for companies with weaker commitment to business ethics. In the case of local evidence Tran (2014) analyses the relation between CEC of German listed companies and corporate governance represented by financial information quality, ownership struc-ture and board remuneration.

The findings show that higher financial transparency and bonus compensations lead to lower cost of capital. Moreover, block ownership is negatively associated with CEC, when block holders are other companies, managers or founding-family members.

Table 2. The categories of corporate governance

\begin{tabular}{|c|c|c|c|c|c|c|c|c|c|}
\hline Authors & 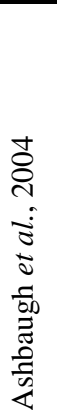 & 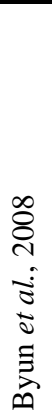 & 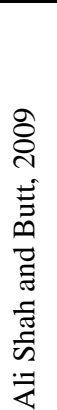 & 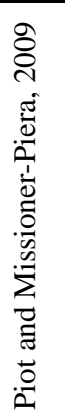 & 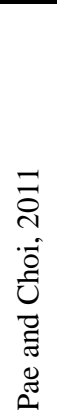 & 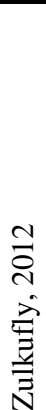 & 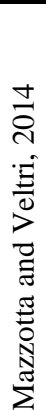 & 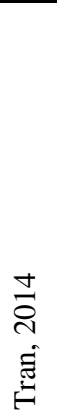 & 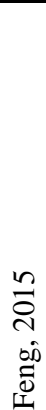 \\
\hline Information quality and disclosure & + & + & & + & & + & & + & \\
\hline Ownership structure & + & & + & & + & & & + & \\
\hline Shareholder rights & + & + & & + & & + & & & + \\
\hline Board characteristics & + & + & + & + & & + & + & & + \\
\hline Board independence & & & & & + & & + & & \\
\hline Board remuneration & & & & & & + & & + & \\
\hline Audit & & & & & & + & & & \\
\hline Audit committee independence & & + & + & + & & & & & \\
\hline Distribution of the proceeds of operation & & & & + & & & & & \\
\hline Dividend policy & & + & & & & & & & \\
\hline Compensation committee ( policy) & & & & & + & & & & + \\
\hline Independence of internal committees & & & & & & + & + & & \\
\hline Ethical and social activities & & & & & & + & & & \\
\hline Vision and strategy & & & & & & & & & + \\
\hline
\end{tabular}

Source: Authors' composition 


\section{Social factors as non-financial determinants}

Currently, the sociology and psychology have become more integrated into economics as a science. In this context, the social factors represent a new direction in evaluation of the CEC. Researchers start to investigate the influence of social factors on the corporate performance as well as CEC. One of these factors is social disclosure or social responsibility, which closely interconnect with corporate disclosure in general. Richardson and Welker (2001) find that social disclosure positively and significantly influence the costs of equity capital. The social disclosure is a measure that includes 10 categories of information from corporate annual reports: human resources; products; services, and consumers; community; environment; energy resources; governments; suppliers; shareholders; competitors; miscellaneous.

In recent years interest to corporate social responsibility (CSR) has been increased: investors pay attention to social activities of the companies and economists and researchers support companies in social polices improvement. For instance, Ghoul et al. (2011) argue that corporate social responsibility represented by investment in improving responsible employee relations, environmental policies, and product strategies reduce CEC. In global terms the influence of social responsibility on the CEC is investigated by Dhaliwal et al. (2014). Their results show a negative relation between CSR disclosure and the CEC, moreover the association is stronger in stakeholder-oriented countries. In addition there is evidence that financial and CSR disclosures can be substitutes in reducing the CEC.

Later Feng et al. (2015) also analyse the relation between corporate social responsibility and CEC based on the international evidence. They find that CSR is significantly associated with lower CEC in North America and Europe. However in Asian countries the relation is positive. The Commission of the European Union defines CSR as "a concept whereby companies integrate social and envi-ronmental concerns in their business operations and in their interaction with their stakeholders on a voluntary basis". The CSR index consists of four dimensions: environment performance, social performance, economic performance and corporate governance performance. The findings show that in North America economic performance (that includes profitability, long-term growth and cost) has more significant impact on the CEC. At the same time in European countries greater environment protection, social performance or performance management will lead to lower CEC. On the other hand in Asia corporate governance, environment and social performance are significantly positively related to CEC, i.e. stronger social responsibility leads to higher CEC.

The social and environment responsibility can be referred to sustainability as a new popular concept. According to Feng et al. (2015) social performance consists of employment quality, health and safety, training and development, diversity, human rights, community, product responsibility. $\mathrm{Ng}$ and Rezaee (2015) investigate the relation between CEC and business sustainability, as well as envi-ronmental, social and governance performance. The findings prove that economic sustainability disclosure negatively influences the CEC; moreover, growth and research factors contribute in this relation. In addition, the non-financial dimensions of sustainability as environmental and governance performance reduce CEC. However social sustainability performance is not significantly related to CEC.

Environmental performance as a part of social responsibility might include resource reduction, emission reduction and product innovation (Feng et al., 2015; Tvaronavičienė, 2018). Sharfman and Fernando (2008) ana-lyse the environmental performance and its influence on the CEC. The higher level of environmental risk management make a company more legitimate and increase investors' confidence that in turn leads to lower CEC. The environmental risk management is measured by quantitative measures as Toxic Release Inventory (TRI) data (data about the use, emission and disposal of ca. 600 toxic elements) and qualitative measures (based on the 
Kinder, Lydenberg, Domini \& Co, Inc. or KLD social performance score). The findings show that stronger environmental risk management reduced CEC.

In the same way corporate ethic or ethical commitment has become one of the important non-financial factors influencing corporate performance, including CEC. The degree of corporate ethic can be measured by indices. For example, Choi and Jung (2008) combines corporate ethical com-mitment index based on the self-administrated anonymous questionnaires, which includes implicit dimensions of ethical commitment (top management support, corporate culture, ethical leadership, open communication channels and ethical training) and explicit dimensions (codes of ethics, ethics hotlines, ethics officers and ethics committees). Later based on corporate ethical commitment index Choi (2012) investigates the influence of corporate ethics on the CEC and finds significantly nega-tive relation between two variables for companies listed on the Korean stock market.

Extending the comprehension of non-financial performance the marketing and advertisement might influence the corporate financial performance through earnings growth and expected cash flow in-crease. For instance Singh et al. (2005) analyse the influence of product market advertising on the cost of capital, including CEC. The study shows the negative relation between advertising expenses and CEC for U.S. companies. Marketing expenses (among them advertisement) are aimed to create customer loyalty, promote a brand, generate higher margins and increase revenue. Moreover, the advertisement might improve the shareholder value. An increased visibility among customers and investors will lead to a higher liquidity and the spread of the stocks on the market.

Another research on the relation between non-financial performance and the cost of capital is con-ducted by Himme and Fischer (2014). They investigate the influence of customer satisfaction, brand value and corporate performance on the cost of capital, including CEC. The findings show that only higher satisfaction ratings decrease CEC. Customer satisfaction plays a significant information role as it reflects customers' experience in the past and assumes customers' willing to come back or recommend a company that in turn might lead to earnings increase and the higher future cash flows. In another words the customer satisfaction provides information about customers' willingness to pay thus expected earnings. At the same time, authors do not find strong evidence on the relation be-tween brand value and corporate reputation and the CEC.

Summing up, the non-financial performance as social factors significantly influences the CEC. Moreover, the improvement of such factors as social disclosure and social responsibility, employee relations, product strategies, environmental performance, environmental risk management will lead to lower CEC.

\section{How to reduce cost of equity capital?}

Based on the literature review regarding the internal factors a strategy how to decrease the CEC has been generated. This strategy is focused on internal factors adjustments that in turn lead to lower CEC. In terms of accounting information and corporate disclosure the strategy how to decrease the CEC is shown in Scheme 1.

Summing up, the companies can adjust the CEC by means of influence of the internal factors as the quality and quantity of accounting information, the accounting systems and standards, the type of disclosure. The information environment influences the companies' decision-making process and has a direct influence on the CEC and its management by the estimation risk and information asymmetry reduction. However, there are continuous debates between proponents and opponents of greater discloser, because it is difficult to quantify and establish the benefits of discloser. 


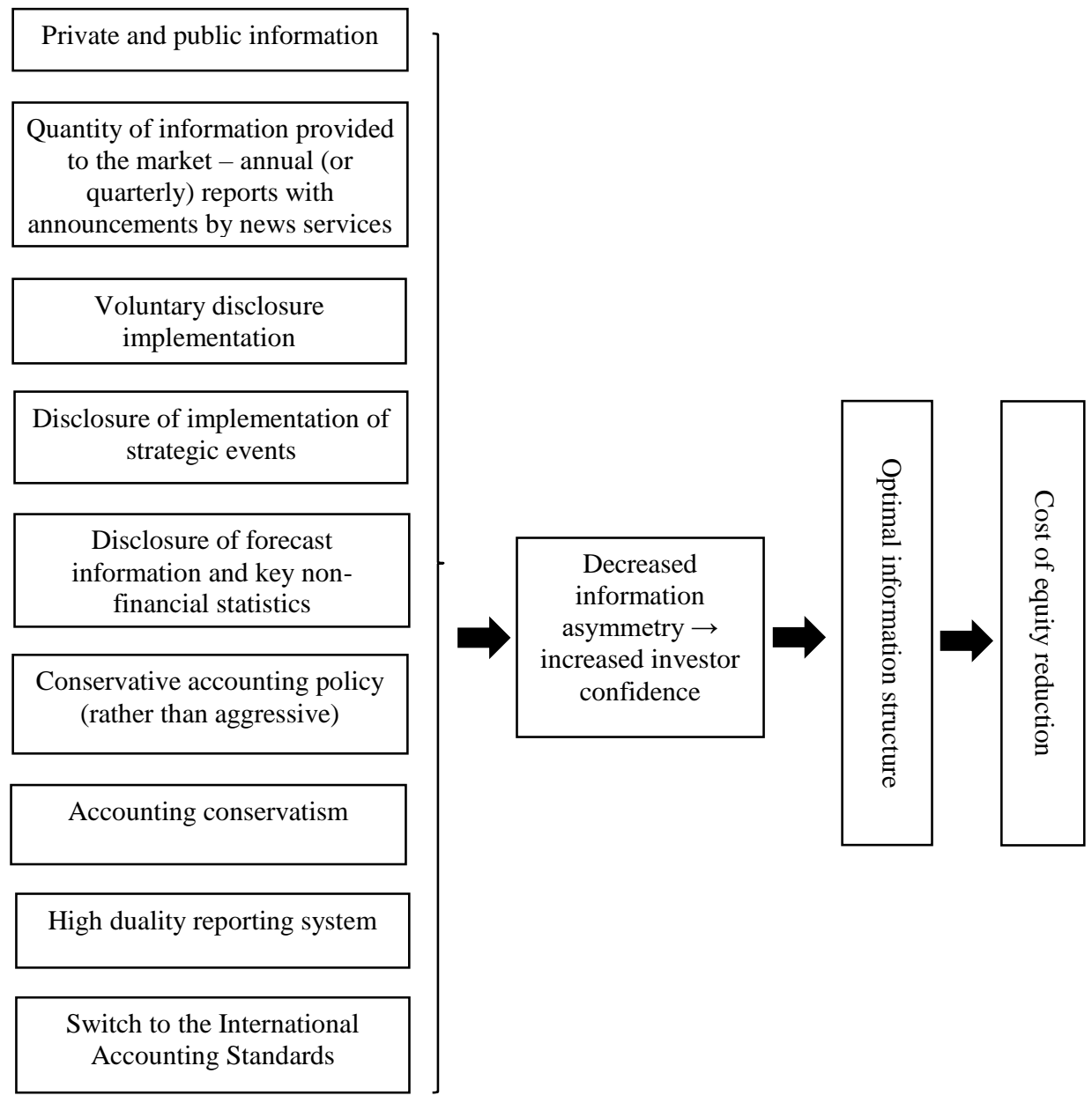

Scheme 1. How to reduce the cost of equity in terms of accounting a disclosure?

Source: Authors' composition

The strong corporate governance and its attributes reduce the CEC by decreasing the agency problems and information asymmetry. The conducted analysis of previous studies contributes towards the following set of recommendations, which companies may adopt in their financial strategies. Firstly, board independence should be improved, i.e. the number of independent directors should be increased. Next measures concern board size adjustment, establishing of independent audit commit-tee and its sizing ( $4-5$ members on average), auditors' compensation adjustment, increasing of investors' protection and shareholder rights improvement. 
Strong corporate governance provides effective financial decisions connecting with the cost of capital and solves information asymmetry problems reducing moral hazard at the same time. Those problems can be arisen because of low quality of management and imperfection of information on the market about the real company's value. In addition, strong corporate governance includes positive abnormal returns, higher firms value, higher profits, higher sales growth, fewer corporate ac-quisitions and lower capital expenditures.

The non-financial performance as social factors also influences the CEC significantly. The improvements of these factors should be focused on higher social disclosure, stronger social responsibility, improvements in responsible employee relations, improvements in product strategies, stronger social performance as employment quality, health and safety, training and development, diversity, human rights, community and product responsibility. Attention should be also payed to stronger social commitment as top management support, corporate culture, ethical leadership, open commu-nication channels as well as to the existence of codes of ethics, stronger environmental performance, higher marketing expenses and higher customer satisfaction.

All these improvements of internal factors might support companies to reduce the CEC.

\section{Conclusions}

In this paper we compiled and accumulated knowledge on the relation between internal factors and the cost of equity.

The internal factors can be divided into three main categories: disclosure policy, corporate governance and social factors. All these internal factors might reduce the CEC. The most important factor that links together internal factors and CEC is information asymmetry. Researchers agree on that lower information asymmetry leads to lower CEC. The disclosure policy and its elements reduce the CEC. Likewise the stronger corporate governance by itself and its components lead to lower CEC. The frontier in the CEC research concerns social factors. The studies show that stronger social responsibility and corporate ethics decrease the CEC. Moreover, the improvements in environmental performance can be used to adjust the level of equity capital costs. The complex knowledge regarding the CEC reduction might support the decision-making process in terms of capital management and represents a tool of more efficient management in terms of financing.

We believe that our systematic review facilitates the understanding of the consistent patterns inside the company and interrelations between essential corporate elements and provides a solid theoretical background for further research in terms of the CEC.

\section{References}

Aboody, D.; Hughes, J.; \& and Liu, J. 2005. Earnings quality, insider trading and cost of capital, Journal of Accounting Research, 43(5): 651-673. http://dx.doi.org/10.2139/ssrn.488203

Ali Shah, S. Z.; \& Butt, S. A. 2009. The Impact of Corporate Governance on the Cost of Equity: Empirical Evidence from Pakistani Listed Companies, The Lahore Journal of Economics, 14(1): 139-171

Armstrong, C. S.; Core, J. E.; Taylor, D. J.; \& Verreccia, R. E. 2011. When Does Information Asymmetry Affect the Cost of Capital? Journal of Accounting Research, 49(1): 1-40. https://doi.org/10.1111/j.1475-679X.2010.00391.X 
Artiach, T.; \& Clarkson, P. 2010. Conservatism, disclosure, and the CEC, University of Queensland. Available at: http://papers.ssrn.com/sol3/papers.cfm?abstract_id=1673516 [Accessed: 2017, August 13]

Artiach, T.C.; \& Clarkson, P. M. 2011. Disclosure, conservatism and the CEC: a review of the foundation literature. Accounting and Finance, 51(1): 2-49. https://doi.org/10.1111/j.1467-629X.2010.00387.x

Apergis, N.; Artikis, G.; Eleftheriou, S.; \& Sorros, J. 2012. Accounting information and excess stock returns: the role of the cost of capital - new evidence from US firm-level data, Applied Financial Economics, 22(4): 321-329. https://doi.org/10.1080/09603107.2011.613756

Apergis, N.; Artikis, G.; Eleftheriou, S.; \& Sorros, J. 2011. Accounting information and cost of capital: a theoretical approach, Modern Economy, 2: 589-596. https://doi.org/10.4236/me.2011.24066

Baginski, S. P.; \& Rakow, K. C. 2012. Management earnings forecast disclosure policy and the CEC, Rev Account Stud., 17(2): 279-321. http://dx.doi.org.ezproxy.lib.vutbr.cz/10.1007/s11142-011-9173-4

Barth, M. E.; Konchitchki, Y.; \& Landsman, W. R. 2013. Cost of capital and earnings transparency, Journal of Accounting and Economics, 55(2-3): 206-224. http://dx.doi.org.ezproxy.lib.vutbr.cz/10.1016/j.jacceco.2013.01.004

Barron, O.; Sheng, X.; \& Thevenot, M. 2012. Information Environment and the Cost of Capital: A New Approach, American University. Available at: http://www.american.edu/cas/economics/research/upload/2012-12.pdf

Basu., S. 1997. The conservatism principle and the asymmetric timeliness of earnings, Journal of Accounting and Economics, $24(1)$ : 3-37. https://doi.org/10.1016/S0165-4101(97)00014-1

Beaver, W. H.; \& Ryan, S. G. 2005. Conditional and unconditional conservatism: concepts and modelling, Review of Accounting Studies, 10(2-3): 269-309. https://doi.org/10.1007/s11142-005-1532-6

Bushman, R. M.; Piotroski, J. D.; \& Smith, A. J. 2004. What determines corporate transparency? Journal of Accounting Research, 42(2): 207-252. https://doi.org/10.1111/j.1475-679X.2004.00136.x

Byun, H. Y.; Kwak, S. K.; \& Hwang, L. S. 2008. The implied cost of equity capital and corporate governance practices, Asia-Pacific Journal of Financial Studies, 37(10): 139-184.

Chan A.; Lin S.; \& Strong N. 2009. Accounting conservatism and the cost of equity capital: UK evidence, Managerial Finance, 35(4): 325-345. https://doi.org/10.1108/03074350910935821

Chen, Z.; Dhaliwal, D. S.; \& Xie, H. 2010. Regulation fair disclosure and the cost of equity capital, Review of Accounting Studies, 15: 106144. https://doi.org/10.1007/s11142-009-9115-6

Choi, T. 2012. Do ethical companies have lower implied cost of equity capital? Evidence from the Korean stock market, Asian Business \& Management, 11(2): 219-246. https://doi.org/10.1057/abm.2011.32

Choi, T.; \& Jung, J. 2008. Ethical commitment, financial performance and valuation: An empirical investigation of Korean companies, Journal of Business Ethics, 81(2). p. 447-463. https://doi.org/10.1007/s10551-007-9506-1

Claessens, S.; \& Yortoglu, B. B. 2013. Corporate governance in emerging markets: A survey, Emerging Markets Review, 15: 1-33. https://doi.org/10.1016/j.ememar.2012.03.002

Copeland, T. E.; \& Galai, D. 1983. Information effects on the bid-ask spreads, Journal of Finance, 38(5): 1457-1469. https://doi.org/10.2307/2327580

Core, J. E.; Hail, L.; \& Verdi, R. S. 2014. Mandatory Disclosure Quality, Inside Ownership, and Cost of Capital, European Accounting Review, 24(1): 1-29. http://dx.doi.org/10.2139/ssrn.2443982 
Dhaliwal, D.; Li, O. Z.; Tsang, A.; \& Yang, Y. G. 2014. Corporate social responsibility disclosure and the cost of equity capital: The roles of stakeholder orientation and financial transparency, Journal of Accounting and Public Policy, 33(4), 328-355. https://doi.org/10.1016/j.jaccpubpol.2014.04.006

Deboskey, D. G.; \& Gillett, P.R. 2013. The impact of multi-dimensional corporate transparency on us firms' credit ratings and cost of capital, Revue of Quantitative Finance and Accounting, 40: https://doi.org/101-134. 10.1007/s11156-011-0266-8

Dokulil, J., Zlámalová, J., \& Popesko, B. 2017. The perception of budgeting in Czech firms — results of a survey, Oeconomia Copernicana, 8(2), 273-285. https://doi.org/10.24136/oc.v8i2.17

Easley, D.; \& O’Hara, M. 2004. Information and the cost of capital, Journal of Finance, 59(4): 1553-1584. https://doi.org/10.1111/j.1540$\underline{6261.2004 .00672 . x}$

Faldzinski, M.; Balcerzak, A. P.; Meluzin, T.; Pietrzak, M. B.; \& Zinecker, M. 2016. Cointegration of Interdependencies among Capital Markets of Chosen Visegrad Countries and Germany. In: 34th International Conference Mathematical Methods in Economics (MME 2016). Technical University Liberec, 06-09 September. Liberec, Czech Republic, 189-194.

Feng, Z-Y.; Wang, M-L.; \& Huang, H-W. 2015. Equity financing and social responsibility: further international evidence, International Journal of Accounting, 50(3): 247-280. https://doi.org/10.1016/j.intacc.2015.07.005

García Lara, J.M.; García Osma, B.; \& Penalva, F. 2011. Conditional conservatism and the cost of capital, Review of Accounting Studies, 16(2): 247-271. https://doi.org/10.1007/s11142-010-9133-4

Ghoul, S. E.; Guedhami, O.; Kwok, C. Y.; \& Mishra, D. R. 2011. Does corporate social responsibility affect the cost of capital? Journal of Banking \& Finance, 35: 2388-2406. https://doi.org/10.1016/j.jbankfin.2011.02.007

Givoly, D.; \& Hayn, C. 2000. The changing time-series properties of earnings, cash flows and accruals: has financial reporting become more conservative? Journal of Accounting and Economics. 29: 287-320. https://doi.org/10.1016/S0165-4101(00)00024-0

Himme, A.; \& Fischer, M. 2014. Drivers of the cost of capital: the joint role of non-financial metrics, Intern. J. of Research in Marketing, 31(2): 224-238. https://doi.org/10.1016/j.ijresmar.2013.10.006

Kim, J. W.; \& Shi, Y. 2011. Voluntary disclosure and the cost of equity capital: Evidence from management earnings forecasts, J. Account. Public Policy, 30(4): 348-366. https://doi.org/10.1016/j.jaccpubpol.2011.03.001

Kitchenham, B. 2004. Procedures for Performing Systematic Reviews. [Online]. NICTA Technical Report 0400011T.1. Eversleigh, Australia: Empirical Software Engineering, National ICT Australia Ltd. Available at: http://www.inf.ufsc.br/ aldo.vw/kitchenham.pdf

[Accesed: 2018, March 3].

Kovacic, Z., \& Vilotic, M. 2017. Characterising and testing European business cycles asymmetry, Equilibrium. Quarterly Journal of Economics and Economic Policy, 12(3), 453-468. https://doi.org/10.24136/eq.v12i3.24

Kyle, A. S. 1985. Continuous auctions and insider trading, Econometrica, 53(6): 1315- 1336. http://doi.org/10.2307/1913210

Lang, M.; \& Lundholm, R. (1993). Cross-sectional determinants of analyst ratings of corporate disclosures, Journal of Accounting Research, 31(2): 246-271. http://doi.org/10.2307/2491273

Lenart, Ł., Mazur, B., \& Pipień, M. 2016. Statistical analysis of business cycle fluctuations in Poland before and after the crisis, Equilibrium. Quarterly Journal of Economics and Economic Policy, 11(4), 769-783. https://doi.org/10.12775/EQUIL.2016.035

Lopes, A. B.; \& Alencar, R. C. 2010. Disclosure and cost of equity capital in emerging markets: the Brazilian case, The International Journal of Accounting, 45(4): 443-464. https://doi.org/10.1016/j.intacc.2010.09.003

Leuz, R.; \& Verrecchia, R. E. 2000. The economic consequences of increased disclosure, Journal of Accounting Research, 38: 91-124. https://doi.org/10.2307/2672910

Li, G. 2005. Information quality, learning, and stock market returns, Journal of Financial and Quantitative Analysis, 40(3): 595-620. https://doi.org/10.1017/S0022109000001885 
Masood, O.; Aktan, B.; Gavurová, B.; Fakhry, B.; Tvaronavičienė, M., Martinkutė-Kaulienė, R. (2017). The impact of regime-switching behaviour of price volatility on efficiency of the US sovereign debt market, Economic Research-Ekonomska Istraživanja 30(1): 1865-1881 http://dx.doi.org/10.1080/1331677X.2017.1394896

Mazur, B. 2017. Probabilistic predictive analysis of business cycle fluctuations in Polish economy, Equilibrium. Quarterly Journal of Economics and Economic Policy, 12(3), 435-452. https://doi.org/10.24136/eq.v12i3.23

Mazzotta, R.; \& Veltri, S. 2012. The relationship between corporate governance and the cost of equity capital: Evidence from the Italian stock Exchange, Journal of Management \& Governance, 18(2): 419-448. https://doi.org/10.1007/s10997-012-9230-9

McInnis, J. 2010. Earnings smoothness, average returns and implied cost of equity capital, The Accounting Review, 85(1): 315-341. https://doi.org/10.2308/accr.2010.85.1.315

Meluzín, T. Pietrzak, M. B., Balcerzak, A. P., Zinecker, M., Doubravský, K., \& Dohnal, M. 2017. Rumours Related to Political Instability and their Impact on IPOs: The Use of Qualitative Modeling with Incomplete Knowledge, Polish Journal of Management Studies, 16 (2), 171-187. https://doi.org/10.17512/pjms.2017.16.2.15

Michalak, A. 2016. The Cost of Capital in the Effectiveness Assessment of Financial Management in a Company, Oeconomia Copernicana, 7(2): 317-329. https://doi.org/10.12775/OeC.2016.019

Mikhail, M. B.; Walther, B. R.; \& Willis, R. H. 2004. Earnings surprises and the cost of equity capital, Journal of Accounting, Auditing and Finance, 19: 491-513. http://dx.doi.org/10.2139/ssrn.504662

MSCI KLD scores. 2015. Network for Business Sustainability. [Online]. Available at: https://nbs.net/p/msci-kld-scores-495983be-0d3a4b14-ae63-1c7220ceecbf [2018, March 7].

Myers, S. C. 1984. The capital structure puzzle, Journal of Finance, 39(3): 575-592. https://doi.org/10.1111/j.1540-6261.1984.tb03646.x

Myers, S.C.; \& Majluf, N.S. 1984. Corporate financing and investment decisions when firms have information that investors do not have, Journal of Financial Economics, 13(2):187-221. https://doi.org/10.1016/0304-405X(84)90023-0

Myskova, R.; \& Hajek, P. 2016. The Effect of Managerial Sentiment on Market-to-Book Ratio, Transformations in Business \& Economics, 15(2A): 498-513.

Ng, A. C.; \& Rezaee, Z. 2015. Business sustainability performance and cost of equity capital; Journal of Corporate Finance, 34:128-149. https://doi.org/10.1016/i.jcorpfin.2015.08.003

OECD. 2015. G20/OECD Principles of Corporate Governance, Report to G20 finance ministers and central bank governors. Paris.

Pae, J.; \& Choi, T. H. 2011. Corporate governance, commitment to business ethics, and firm valuation: Evidence from the Korean stock market, Journal of Business Ethics, 100(2): 323-348. https://doi.org/10.1007/s10551-010-0682-Z

Paseková, M.; Müllerová, L.; Crhová, Z.; Svitaková, B. 2018. Impact of reporting of deferred tax on sustainable development of a counry: case of Czech Republic, Journal of Security and Sustainability Issues 7(4): 769-779. https://doi.org/10.9770/jssi.2018.7.4(13)

Pieloch-Babiarz, A. 2017. Determinants of payout policy and investment attractiveness of companies listed on the Warsaw Stock Exchange, Equilibrium, Quarterly Journal of Economics and Economic Policy, 12(4): 675-691. https://doi.org/https://doi.org/10.24136/eq.v12i4.35

Pietrzak, M. B., Fałdziński, M., Balcerzak, A. P., Meluzín, T. \& Zinecker, M. 2017. Short-term Shocks and Long-term Relationships of Interdependencies among Central European Capital Markets, Economics \& Sociology, 10(1), 61-77. https://doi.org/10.14254/2071$\underline{789 X .2016 / 10-1 / 5}$

Pustylnick, I. 2017. Comparison of liquidity based and financial performance based indicators in financial analysis, Oeconomia Copernicana, 8(1), 83-97. https://doi.org/10.24136/oc.v8i1.6 
The International Journal

ENTREPRENEURSHIP AND SUSTAINABILITY ISSUES

ISSN 2345-0282 (online) http://jssidoi.org/jesi/

2018 Volume 5 Number 4 (June)

http://doi.org/10.9770/jesi.2018.5.4(9)

Rakow, K. C. 2010. The effect of management earnings forecast characteristics on cost of equity capital, Advances in Accounting, Incorporating Advances in International Accounting, 26: 37-46. https://doi.org/10.1016/j.adiac.2010.02.007

Richardson, A. J.; \& Welker, M. 2001. Social disclosure, financial disclosure and the cost of equity capital, Accounting, Organizations and Society, 26(7-8): 597-616. https://doi.org/10.1016/S0361-3682(01)00025-3

Sharfman, M. P.; \& Fernando, C. S. 2008. Environmental risk management and the cost of capital, Strategic Management Journal, 29: 569-592. https://doi.org/10.1002/smj.678

Singh, M.; Faircloth, S.; \& Nejadmalayeri, A. 2005. Capital market impact of the product marketing strategy: evidence from the relationship between advertising expenses and cost of capital, Journal Academy of Marketing Science, 33(4): 432-444. https://doi.org/10.1177/0092070305277380

Tomczak, S. 2017. Influence of the size of equity on corporate efficiency, Oeconomia Copernicana, 8(2), $239-254$. https://doi.org/10.24136/oc.v8i2.15

Tran, D. H. 2014. Multiple corporate governance attributes and the cost of capital - evidence from Germany, The British Accounting Review, 46(2): 179-197. https://doi.org/10.1016/j.bar.2014.02.003

Tranfield, D.; Denyer, D.; \& Smart, P. 2003. Towards a Methodology for Developing Evidence-Informed Management Knowledge by Means of Systematic Review, The British Journal of Management 14(3): 207-222. https://doi.org/10.1111/1467-8551.00375

Tvaronavičienè, M. 2018. Towards sustainable and secure development: energy efficiency peculiarities in transport sector, Journal of Security and Sustainability Issues 7(4): 719-725. https://doi.org/10.9770/jssi.2018.7.4(9)

Watts, R. L. 2003. Conservatism in accounting Part I: Explanations and implications, Accounting Horizons, 17(3): 207-221. http://dx.doi.org/10.2139/ssrn.414522

Vukovic, D., Hanic, E., \& Hanic, H. 2017. Financial integration in the European Union - the impact of the crisis on the bond market, Equilibrium. Quarterly Journal of Economics and Economic Policy, 12(2), 195-210. https://doi.org/10.24136/eq.v12i2.10

Zinecker, M.; Balcerzak, A. P.; Faldzinski, M.; Meluzin, T.; \& Pietrzak, M. B. 2016. Application of DCC-Garch Model for Analysis of Interrelations among Capital Markets of Poland, Czech Republic and Germany. In: International Scientific Conference on Quantitative Methods in Economics - Multiple Criteria Decision Making XVIII. Univ Econ Bratislava, 25-27 May. Vratna, Slovakia, $416-421$.

Zulkufly, R. 2012. Impact of corporate governance quality on the cost of equity capital in an emerging market: Evidence from Malaysian listed firms, African Journal of Business Management, 6(4): https://doi.org/1733-1748. 10.5897/AJBM10.1624

\section{Aknowledgements}

The research is supported by Institute of Economic Research Torun. Name of the Project: Analysis of Relations among Capital Markets of European Union Countries. Project Registration No. 2016/1. 
The International Journal

ENTREPRENEURSHIP AND SUSTAINABILITY ISSUES

ISSN 2345-0282 (online) http://jssidoi.org/jesi/

2018 Volume 5 Number 4 (June)

http://doi.org/10.9770/jesi.2018.5.4(9)

Natalia MOKHOVA completed her Ph.D. studies in Business and Finance at Brno University of Technology, Faculty of Business and Management. Her main research area includes external and internal determinants of corporate capital structure.

\section{ORCID ID}

Marek ZINECKER is the Associate Professor at Brno University of Technology, Faculty of Business and Management. His main research areas include macroeconomic factors influencing corporate financing via venture capital and initial public offerings.

ORCID ID: https://orcid.org/0000-0003-1764-0904

Tomáš Meluzín is the Associate Professor at Brno University of Technology, Faculty of Business and Management and Director of the Department of Corporate Economy. His main research interest includes IPO strategy from the perspective of going public companies.

ORCID ID: https://orcid.org/0000-0001-5238-5166

Copyright (C) 2018 by author(s) and VsI Entrepreneurship and Sustainability Center

This work is licensed under the Creative Commons Attribution International License (CC BY).

http://creativecommons.org/licenses/by/4.0/

(c) (i) Open Access 